\title{
PENGARUH MODEL PEMBELAJARAN KOOPERATIF TIPE JIGSAW TERHADAP PENINGKATAN KEMAMPUAN KOMUNIKASI MATEMATIS SISWA MTS
}

\author{
Siti Khayroiyah ${ }^{1)}$, Tanti Jumaisyaroh Siregar ${ }^{2)}$ \\ ${ }^{1}$ FKIP UMN Al-Washliyah Medan \\ Sitikhayroiyah@gmail.com \\ ${ }^{2}$ FKIP UMN Al-Washliyah Medan \\ tanti.jss@gmail.com
}

\begin{abstract}
Tujuan penelitian ini untuk mengetahui pengaruh model pembelajaran kooperatif tipe jigsaw terhadap peningkatan kemampuan komunikasi matematis siswa. Jenis penelitian ini merupakan penelitian eksperimen semu. Variabel penelitian ini terdiri atas variabel bebas yaitu model pembelajaran kooperatif tipe jigsaw dan sedangkan variabel terikatnya yaitu kemampuan komunikasi matematis siswa. Populasi dalam penelitian ini adalah seluruh siswa MTs Lab IKIP Al-Washliyah Medan dan sampel dalam penelitian ini adalah siswa MTs dengan mengambil dua kelas yaitu VIII A dan VIII B secara acak (kelas eksperimen dan kelas kontrol). Teknik pengumpulan data dalam penelitian ini dengan menggunakan tes. Tes yang digunakan yaitu tes kemampuan komunikasi matematis siswa (pre tes dan post tes). Data yang sudah dikumpulkan selanjutnya dianalisis dengan menggunakan uji regresi linear sederhana. Berdasarkan hasil analisis tersebut diperoleh yaitu: terdapat pengaruh model pembelajaran kooperatif tipe jigsaw terhadap peningkatan kemampuan komunikasi matematis siswa. Oleh karena itu, disarankan pembelajaran kooperatif tipe jigsaw dijadikan alternatif bagi guru untuk meningkatkan kemampuan komunikasi matematis siswa.
\end{abstract}

Keywords: Komunikasi Matematis, Pembelajaran Kooperatif Tipe Jigsaw.

\begin{abstract}
The purposes of this research was to know: The influence of cooperative learning type of jigsaw on improving mathematics comunication ability of students. The type of this research was a quasi research. The variable of this research consist of independent variable that was cooperative learning type of jigsaw model and while the dependent variable was mathematics comunication ability of students. The population of this research are all students of MTs Lab IKIP Al-Washliyah Medan and the sample of this research are students of MTS in the VIII class with taken sample two classes namely VIII A dan VIII B by random (experiment and control). The instrument of this research was test. The test that used was mathematics comunication ability (pre test and post test). Data that have been collected then analyzed by using $t$ - test. Based of the results analysis, it showed that: there is the influence of cooperative learning type of jigsaw on improving mathematics comunication ability of students.. His then, suggested that mathematics comucation ability be used as an alternative for teacher to improved students' mathematics comunication ability.
\end{abstract}

Keywords: Mathematics Comunication Ability, Cooperative Learning type of Jigsaw. 


\section{PENDAHULUAN}

Matematika merupakan salah pelajaran yang diberikan kepada siswa untuk tingkat SMP/ MTs. Adapun salah satu tujuan diberikan mata pelajaran matematika di sekolah menengah adalah agar siswa mampu mengkomunikasikan gagasan dengan simbol, tabel, diagram, atau media lain untuk memperjelas keadaan atau masalah (Depdiknas, 2006: 140). Salah satu kemampuan yang harus dimiliki oleh siswa dalam pembelajaran matematika adalah kemampuan komunikasi matematis. Oleh karena itu, setiap siswa harus memiliki kemampuan komunikasi matematis yang baik.

Kemampuan komunikasi matematis penting dimiliki oleh setiap siswa dengan beberapa alasan yaitu : (1) kemampuan komunikasi matematis manjadi kekuatan sentral bagi siswa dalam merumuskan konsep dan strategi; (2) kemampuan komunikasi matematis sebagai modal keberhasilan bagi siswa terhadap pendekatan dan penyelesaian dalam eksplorasi dan investigasi matematika; (3) kemampuan komunikasi matematis sebagai wadah bagi siswa dalam berkomunikasi dengan temannya untuk memperoleh informasi dari berbagai pikiran (Susanto, 2013:214). Selanjutnya, menurut Astuti dan Leonard (2015:103) menyatakan bahwa kemampuan komunikasi matematis memainkan peranan penting sebab jika siswa memiliki kemampuan komunikasi yang baik kemungkinan besar hasil belajar siswa dalam pembelajaran matematika pun akan baik pula.

Namun kenyataannya, hal yang terjadi dalam pembelajaran matematika adalah kebanyakan siswa yang masih bingung memahami soal atau data yang ada pada soal dan meyatakannya dalam bentuk matematis, sulit menentukan konsep yang digunakan untuk menyelesaikan masalah, bingung membaca serta menginterpretasi data yang tersaji dalam bentuk diagram, grafik maupun gambar (Ranti : 2015, 97). Hal ini juga didukung berdasarkan hasil pengamatan dan observasi yang dilakukan oleh Sefalianti (2014) di kelas VII SMP Negeri 2 Way Seputih, Istiqomah (2014) di SMP Negeri 2 Sedayu, Hadijah dkk (2016) di kelas VIII SMP Negeri 4 Percut Sei Tuan dan juga penelitian awal yang dilakukan oleh peneliti kepada siswa MTs UMN Al-Washliyah Medan menunjukkan bahwa kemampuan komunikasi matematis siswa masih rendah.

Kemampuan komunikasi matematis siswa yang masih rendah disebabkan oleh beberapa faktor salah satu faktor diduga mempengaruhi adalah pembelajaran yang dilakukan oleh guru masih berpusat kepada guru. Hal ini berdasarkan hasil pengamatan peneliti di MTs Lab IKIP AlWashliyah Medan yang menunjukkan bahwa guru matematika masih menggunakan pembelajaran yang berpusat pada guru (teacher centered learning) atau pembelajaran langsung di kelas.

Menurut Kuhn (dalam Eggen dan Kauchak, 2012:363) bahwa pembelajaran langsung adalah pembelajaran yang mana guru memberikan penjelasan dan demonstrasi kemudian memberikan latihan dan umpan balik kepada siswa melalui fase perkenalan dan review, presentasi, latihan terbimbing dan latihan mandiri untuk membantu mereka mendapat pengetahuan dan keterampilan nyata yang mereka butuhkan untuk pembelajaran selanjutnya. Jadi, pada pembelajaran langsung siswa diberikan informasi secara langsung oleh guru terkait dengan materi yang dipelajarinya sehingga kemampuan komunikasi siswa dalam menyampaikan ide-idenya dalam menyelesaikan masalah tidak dapat berkembang secara optimal.

Oleh karena itu, guru perlu memilih suatu model pembelajaran yang tepat untuk mempengaruhi peningkatan kemampuan komunikasi siswa. Salah satu model pembelajaran yang dapat diterapkan adalah pembelajaran kooperatif tipe jigsaw.

Pembelajaran kooperatif tipe jigsaw dipilih karena pada pembelajaran kooperatif tipe jigsaw akan menjadikan setiap siswa sebagai seorang yang ahli di sub bagian tertentu dan akan mengajarkan 
sub bagian yang ia kuasai dengan teman sekelompoknya. Hal ini tentu akan menimbulkan interaksi antar siswa dalam kelompok sehingga dapat meningkatkan kemampuan komunikasi siswa (Eggen dan Kauchak, 2012:137).

Selanjutnya, hal tersebut juga didukung dengan hasil penelitian Heryani (2014) yang menunjukkan bahwa terdapat pengaruh antara model pembelajaran kooperatif terhadap peningkatan kemampuan komunikasi matematis siswa. Berdasarkan penjelasan di atas, peneliti tertarik untuk mengadakan penelitian dengan judul 'Pengaruh Model Pembelajaran Kooperatif Tipe Jigsaw terhadap Peningkatan Kemampuan Komunikasi Matematis Siswa MTs".

\section{METODE PENELITIAN}

Jenis penelitian ini adalah penelitian eksperimen semu atau quasi eksperiment. Penelitian ini dilakukan di MTs Lab IKIP Al-Washliyah Medan yang beralamat di Jalan Garu II No. 93 Medan. Kegiatan penelitian dilakukan pada semester ganjil Tahun Ajaran 2018/2019. Populasi dalam penelitian ini adalah seluruh siswa MTs Lab IKIP Al-Washliyah Medan. Sampel penelitian dipilih secara acak (cluster random sampling).dimana sampel dalam penelitian ini adalah siswa MTs kelas VIII dengan mengambil dua kelas secara acak yaitu VIII A sebagai kelas ekperimen dan VIII B sebagai kelas kontrol. Dalam penelitian ini melibatkan dua jenis variabel yaitu : kemampuan komunikasi matematis siswa yang diajar dengan menggunakan pembelajaran kooperatif tipe jigsaw dan kemampuan komunikasi matematis siswa yang diajar dengan menggunakan pembelajaran langsung. Adapun desain penelitian ini adalah sebagai berikut: Kelompok Eksperimen $0_{1} \mathrm{X}_{2}$

Kelompok Kontrol $\quad 0_{1} \quad \mathbf{O}_{2}$

Keterangan :

$X=$ Perlakuan berupa pembelajaran kooperatif tipe jigsaw

$0_{1}=$ Pre tes kemampuan komunikasi matematis
$0_{2}=$ Post tes kemampuan komunikasi matematis

Instrumen penelitian yang akan digunakan dalam penelitian adalah tes kemampuan komunikasi matematis. Data yang diperoleh dari hasil penelitian dianalisis secara statsitik dan dideskripsikan. Adapun analisis tatistik yang digunakan adalah analisis independent sample T-test.

\section{HASIL DAN PEMBAHASAN \\ 3.1. Hasil Penelitian}

Kemampuan komunikasi matematis siswa diukur dengan menggunakan tes kemampuan komunikasi matematis yang terdiri atas empat soal yang berbentuk uraian. Adapun ringkasan hasil pre-test kemampuan komunikasi matematis siswa dapat dilihat pada tabel berikut.

Tabel 1 Ringkasan Skor Pre Test Kemampuan Komunikasi Matematis Siswa

\begin{tabular}{lllll}
\hline Kelas & $X_{\min }$ & $X_{\text {maks }}$ & $\bar{X}$ & $S D$ \\
\hline Eksperimen & 1 & 5 & 3.22 & 1.157 \\
\hline Kontrol & 1 & 8 & 3,44 & 1.343 \\
\hline
\end{tabular}

Dari Tabel 1 di atas tampak bahwa pre-test pada kelas eksperimen diperoleh skor terendah 1 , skor tertinggi 5 , rata-rata 3,22 dan standar deviasi sebesar 1,157. Sedangkan untuk pre tes di kelas kontrol diperoleh skor terendah 1 , skor tertinggi 8 , rata-rata 3,44 dan standar deviasi sebesar 1,343. Skor maksimum dan minimum untuk kelas eksperimen dan kontrol jika dilihat tampak tidak jauh berbeda. Hal tersebut juga tampak pada skor rata-rata pre tes kemampuan komunikasi matematis di kelas eksperimen dan kontrol yang tidak jauh berbeda yaitu 3,22 dan 3,44 dimana selisih skor pre test kemampuan komunikasi matematis untuk kedua kelas tersebut hanya sekitar 0,22.

Selanjutnya, baik pada siswa di kelas eksperimen dan siswa pada kelas kontrol diberikan soal post test yang berbentuk uraian. Adapun hasil skor post test kemampuan komunikasi matematis 
mahasiswa dapat dilihat pada tabel berikut ini.

Tabel 2 Ringkasan Skor Pre Test Kemampuan Komunikasi Matematis Siswa

\begin{tabular}{lllll} 
Kelas & $X_{\min }$ & $X_{\text {maks }}$ & $\bar{X}$ & $S D$ \\
\hline Eksperimen & 7 & 10 & 8.78 & 0.920 \\
\hline Kontrol & 5 & 9 & 6.91 & 0.893 \\
\hline
\end{tabular}

Dari tabel 2 di atas tampak bahwa pada kelas eksperimen diperoleh skor terendah 7 , skor tertinggi 10 , rata-rata 8,78 dan standar deviasi sebesar 0,920. Sedangkan pada kelas kontrol diperoleh skor terendah 5, skor tertinggi post-test 9, rata-rata 6,91 dan standar deviasi sebesar 0,893. Jadi, dapat disimpulkan bahwa ratarata skor kemampuan komunikasi matematis baik pada kelas eksperimen dan kontrol terjadi peningkatan. Namun, jika dibandingkan skor rata-rata pada kelas eksperimen lebih tinggi dibandingkan pada kelas kontrol. Hal ini menunjukkan terdapat perbedaan rata-rata skor post test antara kelas eksperimen dan kelas kontrol dimana selisih niai rata-rata antar dua kelompok tersebut yaitu 1,87.

Sebelum pengujian hipotesis, dilakukan pengujian normalitas dan homogenitas. Berdasarkan pengujian normalitas dan homogenitas bahwa data post test kemampuan komunikasi matematis kedua sampel berdistribusi normal dan memiliki varians yang sama.

Pengujian hipotesis dilakukan dengan menggunakan independent sample T-tes dengan menggunakan program SPSS 17 for windows. Ringkasan hasil analisis pengaruh model pembelajaran kooperatif tipe jigsaw terhadap kemampuan komunikasi matematis mahasiswa dapat dilihat pada tabel berikut.

\section{Tabel 3 Ringkasan Hasil Uji Independent Sample T-test}

\begin{tabular}{ccccc}
\hline $\begin{array}{c}\text { Dependent } \\
\text { Variable }\end{array}$ & $\begin{array}{c}\text { Leven } \\
\text { test }\end{array}$ & \multicolumn{3}{c}{$\begin{array}{c}\text { t-test for } \\
\text { Equality }\end{array}$} \\
\hline $\mathrm{F}$ & Sig & $\mathrm{T}$ & $\begin{array}{c}\text { Sig(2- } \\
\text { tailed) }\end{array}$ \\
\hline $\begin{array}{c}\text { Pemecahan } \\
\text { Masalah }\end{array}$ & 0,087 & 0,769 & 8,884 & 0.000 \\
\hline \multicolumn{2}{c}{ Pengambilan } & keputusan diambil
\end{tabular}

dengan membandingkan nilai signifikansi dengan nilai alpha. Jika nilai signifikansi lebih kecil dari $5 \%$, maka $\mathrm{H}_{0}$ ditolak dan Ha diterima, sebaliknya jika nilai signifikansi lebih besar dari $5 \%$ maka $\mathrm{H}_{0}$ diterima dan Ha ditolak.

Berdasarkan tabel 3 diperoleh hasil analisis dengan uji independent T-test yang menunjukkan bahwa nilai signifikansi $0,000<0,05$. Hal ini berarti $\mathrm{H}_{0}$ ditolak dan $\mathrm{H}_{\mathrm{a}}$ diterima yaitu terdapat perbedaan yang signifikan antara kemampuan komunikasi matematis siswa pada kelas eksperimen yang diajar dengan model pembelajaran kooperatif tipe jigsaw dan kemampuan komunikasi matematis siswa pada kelas kontrol yang diajar dengan model pembelajaran langsung.

Hal ini didukung dengan perbedaan rata-rata hasil kemampuan komunikasi matematis yang diajar dengan pembelajaran kooperatif tipe jigsaw dan yang diajar dengan pembelajaran langsung. Hasil kemampuan komunikasi matematis yang diajar dengan pembelajaran kooperatif tipe jigsaw lebih tinggi daripada kemampuan komunikasi matematis yang diajar dengan pembelajaran langsung. Hal ini menunjukkan model pembelajaran kooperatif tipe jigsaw mempengaruhi kemampuan komunikasi matematis siswa. Jadi, dapat disimpulkan terdapat pengaruh antara model pembelajaran kooperatif tipe jigsaw terhadap kemampuan komunikasi matematis siswa.

\subsection{Pembahasan Penelitian}

Berdasarkan hasil penelitian yang diperoleh maka akan dibahas hubungannya dengan tujuan yang telah ditetapkan.. Secara lengkap uraian tersebut akan disajikan dalam bentuk deskripsi berikut ini. 


\subsubsection{Faktor Pembelajaran}

Salah satu faktor yang paling berpengaruh terhadap kemampuan komunikasi matematis siswa adalah pembelajaran khususnya pembelajaran kooperatif tipe jigsaw. Pembelajaran kooperatif tipe jigsaw yang diterapkan pada kelas eksperimen dimulai dari pembagian kelompok tim ahli dimana masing-masing tim ahli akan diberikan beberapa bagian materi untuk dipelajari lebih mendalam. Langkah selanjutnya yaitu mengumpulkan informasi dimana siswamengumpulkan pengalaman mereka dan menyusun informasi untk menyelesaikan masalah yang diberikan. Selanjutnya, langkah yang dilakukan adalah diskusi ahli dimana setiap anggota tim ahli masing-masing kelompok berkumpul untuk menyelsaikan masalah dan selanjutnya mempersentasekan informasi yang mereka diskusikan kepada kelompok mereka. Hal ini dapat mengembangkan interaksi sosial antar siswadalam kelompok yang mana pada akhirnya dapat mengembangkan kemampuan komunikais matematis siswa.

Berdasarkan uraian di atas dari kedua pembelajaran ini terdapat perbedaan pada proses pembentukan pengetahuan yang dilakukan guru. Perbedaan inilah yang dianggap mendukung hasil penelitian yang menunjukkan bahwa pembelajaran kooperatif tipe jigsaw efektif mempengaruhi kemampuan komunikasi siswa daripada pembelajaran langsung.

\subsubsection{Kemampuan \\ Komunikasi \\ Matematis}

Kemampuan komunikasi matematis adalah kemampuan siswa dalam menyampaikan ide atau gagasannya dalam memecahkan masalah melalui lisan maupun tulisan yang meliputi kemampuan siswa menyatakan ide matematika ke dalam bentuk gambar, menyatakan gambar ke dalam ide matematika, dan menyatakan ide matematika ke dalam model matematika..

Dari hasil penelitian ini diperoleh bahwa kemampuan komunikasi matematis siswa dari hasil pre test menunjukkan tidak jauh berbeda dimana skor rata-rata pre tes kemampuan komunikasi matematis di kelas eksperimen dan kontrol yang tidak jauh berbeda yaitu 3,22 dan 3,44 dimana selisih skor pre test kemampuan komunikasi matematis untuk kedua kelas tersebut hanya sekitar 0,22.

Selanjutnya, skor hasil post test kemampuan komunikasi siswa pada kelas eksperimen yaitu 8,78 dan pada kelas kontrol yaitu 6,91. Jadi, dapat disimpulkan skor rata-rata pada kelas eksperimen lebih tinggi dibandingkan pada kelas kontrol. Hal ini menunjukkan terdapat perbedaan ratarata skor post test antara kelas eksperimen dan kelas kontrol dimana selisih niai ratarata antar dua kelompok tersebut yaitu 1,87 .

Berdasarkan pengujian normalitas dan homogenitas di atas disimpulkan bahwa data post tes kemampuan komunikasi matematis kedua sampel berdistribusi normal dan memiliki varians yang sama. Selanjutnya, setelah dilakukan pengujian hipotesis menunjukkan bahwa nilai signifikansi $0,000<0,05$. Hal ini berarti $\mathrm{H}_{0}$ ditolak dan $\mathrm{H}_{\mathrm{a}}$ diterima yaitu terdapat perbedaan yang signifikan antara kemampuan komunikasi matematis siswa pada kelas eksperimen dan kelas kontrol.

Hasil kemampuan komunikasi matematis yang diajar dengan pembelajaran kooperatif tipe jigsaw lebih tinggi daripada kemampuan komunikasi matematis yang diajar dengan pembelajaran langsung. Hal ini menunjukkan model pembelajaran kooperatif tipe jigsaw mempengaruhi kemampuan komunikasi matematis siswa. Jadi, dapat disimpulkan terdapat pengaruh antara model pembelajaran kooperatif tipe jigsaw terhadap kemampuan komunikasi matematis siswa.

\section{KESIMPULAN}

Berdasarkan rumusan masalah, hasil penelitian, dan pembahasan seperti yang telah dikemukakan sebelumnya, diperoleh bahwa terdapat pengaruh antara pembelajaran kooperatif tipe jigsaw 
terhadap kemampuan komunikasi matematis siswa.

\section{REFERENSI}

Astuti, A., dan Leonard. 2015. Peran Kemampuan Komunikasi Matematika Terhadap Prestasi Belajar Matematika Siswa. Jurnal Format (Online). Vol.

No.2.(journal.lppmunindra.ac.id/inde x.php/Formatif/article/viewFile/91/8 8, diakses 15 Agustus 2017).

Depdiknas. 2006. Standar Isi Mata Pelajaran Matematika Tingkat Sekolah Dasar dan Menengah. Jakarta: Depdiknas.

Eggen, P dan Kauchak, D. 2012. Strategi dan Model Pembelajaran. Terjemahkan oleh Satrio Wahono. 2012. Jakarta: PT Indeks.

Hadijah, S., Hasratuddin., Napitupulu, E. 2016. Pengaruh Pembelajaran Kooperatif Terhadap Kemampuan Pemahaman Konsep dan Komunikasi Matematik Siswa SMP Negeri Percut Sei Tuan. Jurnal Tabularasa PPS UNIMED. Vol 13 No.3,(http://jurnal.unimed.ac.id/20 12/index.php/tabularasa/article/vie wFile/458 4/4017, diakses 20 Agustus 2017).

Heryani, $\quad Y . \quad 2014 . \quad$ Peningkatan Kemampuan Koneksi dan Komunikasi Matematik Melalui Pembelajaran Kooperatif Tipe Jigsaw Pada Peserta Didik SMK Negeri di Kabupaten

Kuningan. Jurnal Pendidikan dan Keguruan. (Online).

Vol. $1 \quad$ No. 1.

(http://pasca.ut.ac.id/journal/index. $\mathrm{php} / \mathrm{JPK} / \mathrm{article} / \mathrm{view} / 5$, diakses 11 Agustus 2018).
Istikomah, D.A. 2014. Upaya Peningkatan Kemampuan Komunikasi Matematis Siswa Dengan Model Pembelajaran Kooperatif di SMP N 2 Sedayu Yogyakarta. Jurnal Pendidikan Matematika FKIP Univ. Muhammadiyah Metro. Vol. 3 No.2, (http://fkip.ummetro.ac.id/journal/in dex.php/matematika/article/view/33 3, diakses 21 Agustus 2017).

Ranti, M.G. 2015. Meningkatkan Kemampuan Komunikasi Matematis Siswa Menggunakan Strategi Writing To Learn Pada Siswa SMP. Math Didactic Jurnal Pendidikan Matematika, (Online), Vol. 1 No. 2 , (www.stkipbjm.ac.id/jurnal/index.p hp/math/article/viewFile/22/19 